\title{
PROPOSED FEDERAL CORRECTIONS ACT
}

\author{
OrIe L. PhILIIPS*
}

A Committee on Punishment for Crime ${ }^{1}$ of the Conference of Senior Circuit Judges, at the last meeting of the Conference held in Washington, September 29 to October 2, 1942, submitted a report and a proposed act to provide a correctional system for adult and youthful offenders convicted in courts of the United States. The Conference adopted the report and urged the passage of the bill proposed therein.

Under the proposed act a Board of Corrections ${ }^{2}$ is to be created in the Department of Justice, consisting of ten members appointed by the Attorney General. The terms of the members first appointed are to be staggered. Their successors are to be appointed for terms of six years. One member is to be designated by the Attorney General to act as chairman.

The Board is to comprise a Division on Adult Corrections, ${ }^{3}$ a Youth Authority Division, ${ }^{4}$ and a Policy Division. Members of the Division and the Authority are to be designated by the chairman. In order to afford flexibility, the chairman from time to time may assign one or more members of the Division to serve also on the Authority and one or more members of the Authority to serve also on the Division.

Two members of the Board, one designated by the Division and one designated by the Authority, and the Director of the Bureau of Prisons ${ }^{5}$ are to constitute the Policy Division.

The Policy Division is to hold stated meetings to consider problems of treatment and correction and lay down general treatment and correctional policies to be carried out by the Director. A chief parole officer is to be appointed by the Attorney General who shall administer the parole system and the supervision of youth offenders on conditional release in accordance with general policies laid down by the Policy Division.

\footnotetext{
" I903-1904, Knox College; J.D., 1908, LL.D., 1935, University of Michigan; Dr. Engincering (hon.), 1940, Colorado School of Mines. Member of the New Mexico Bar. Judge of the United States Court of Appeals for the Tenth Judicial Circuit, since 1929; United States District Judge, District of New Mexico, 1923-1929. Visiting Professor of Law, Northwestern University, summers of 1936 and 1937, University of Michigan, summer of 1938 . Member of the Council of the American Law Institute.

2 The Committee was comprised of Circuit Judges John J. Parker (chairman), Learned Hand, and Orie L. Phillips, and District Judges Carroll C. Hincks, John C. Collet, Paul J. McCormick, and Bolitha J. Laws. The Committee created a'Subcommittee on Sentencing of Adult Offenders, comprising Judges Laws (chairman), Hand, and McCormick, and a Subcommittee on Treatment of Youthful Offenders, comprising Judges Phillips (chairman), Hincks, and Collet.

${ }^{2}$ Hereinafter called the Board.

"Hercinafter called the Authority.

${ }^{3}$ Hereinafter called the Division.

- Hereinafter called the Director.
} 
The Board is authorized to adopt and promulgate rules and regulations necessary to effectuate the purposes of the act.

The powers of the District Judge to place an offender on probation are in nowise disturbed by the act.

A youth offender is defined as a male person under the age of 24 years at the time of conviction.

If the court shall find that a convicted person is a youth offender and the offense is punishable by imprisonment, the court may, as a penalty for the offense and in lieu of the penalty otherwise provided by law, sentence the youth offender to the custody of the Authority for treatment and supervision until discharged as provided in the act. If the court shall find that the youth offender does not need treatment, he may suspend the imposition or execution of sentence and place the youth offender on probation. If the court shall find the youth offender will not derive benefits from the treatment and should not be committed to the Authority, he may sentence the youth offender under any other applicable penalty provision, but when the sentence is to imprisonment for a term of more than one year, the sentence must be imposed pursuant to the provisions of Title II of the act dealing with the sentencing of adult offenders.

Youth offenders committed to the Authority shall undergo treatment in institutions of maximum, medium, or minimum security types, including training schools, hospitals, farms, forestry and other camps that will provide the essential varieties of treatment. Treatment is defined in the act as corrective and preventive training and treatment designed to protect the public by correcting the antisocial tendencies of youth offenders.

Classification centers and agencies are to be set up by the Director. Youth offenders committed to the Authority will be sent first to a classification center, where the agency will make a complete study of each youth offender, including a mental and physical examination, to ascertain his personal traits, his capacities, pertinent circumstances of his school, family life, any previous delinquency or criminal experience, and any mental or physical defect or other factor contributing to his delinquency. The agency will then forward to the Authority a report of its findings with respect to the youth offender and its recommendation as to his disposition.

On receipt of such report and recommendation, the Authority will make an order (I) permitting the youth offender to remain at liberty conditionally under supervision, or (2) allocate and direct the transfer of the youth offender to an agency or institution for treatment, or (3) order the youth offender confined under such conditions as it believes best designed for the protection of the public.

The Authority may at any time release conditionally under supervision a youth offender committed to it and may discharge him unconditionally at the expiration of one year from the conditional release. A youth offender committed to the Authority must be released conditionally under supervision on or before the expiration of four 
years from the date of his conviction and must be discharged unconditionally on or before the expiration of six years from the date of his conviction.

Youth offenders permitted to remain at liberty or conditionally released until unconditionally discharged are to be under the supervision of United States probation officers, supervisory agents appointed by the chief parole officer, and voluntary supervisory agents approved by the chief parole officer. The Board is authorized to encourage the formation of voluntary organizations composed of members who will serve without compensation as voluntary supervisory agents. The powers and duties of voluntary supervisory agents are to be limited and defined by regulations adopted by the Board.

Upon the unconditional discharge by the Authority of a youth offender before the expiration of six years from the date of his conviction, the conviction shall be automatically set aside and held for naught, and the Authority will issue to the youth offender a certificate to that effect. The purpose of the last-mentioned provision is to reward the youth for good conduct and favorable reaction to treatment, and to aid him to adjust himself into society upon discharge.

Under Title II of the act, where the judge after a hearing, determines that a sentence of imprisonment for more than one year should be imposed on an offender, he will impose an original sentence to imprisonment generally, which shall be for the maximum term prescribed by law. The court may determine whether sentences on different counts or different indictments shall run concurrently or consecutively. Within six months after an offender commences to serve the original sentence, the Division will recommend to the court the term of imprisonment to be fixed by the different sentences, stating the reasons therefor. The judge will then fix the definite sentence. If the judge fixes a definite sentence which is different from that recommended by the Division he will state his reasons in writing. In determining terms of imprisonment to be recommended by it, the Division will consider all pertinent information and, before making the report and recommendation, one member will personally interview the offender, and he will be afforded a hearing before one or more members of the Division.

Adult offenders and youth offenders not sentenced to the Authority who are sentenced to imprisonment for one year or less are to be committed to institutions, camps, or farms of medium or minimum security, separated, in so far as practical, from other penal and correctional institutions.

The report of the Subcommittee on Treatment of Youthful Offenders ${ }^{B}$ reads:

Our studies of reliable statistics demonstrate that the period in life between 16 and 23 is a focal source of crime. It is during this period that large numbers of habitual criminals are spawned. Persons between the ages of $\mathrm{I} 6$ and $2 \mathrm{I}$ constitute approximately $\mathrm{I} 3$ per cent of our population. They are responsible for approximately 26 per cent of our robberies, in excess of $4^{\circ}$ per cent of our burglaries, and nearly $5^{\circ}$ per cent of our automobile thefts. 1 [ ${ }^{1}$ The Criminality of Youth, Thorsten Sellin, p. 3r.] Young men in the age group be-

- Report of Subcommittee on Treatment of Youthful Offenders, REPORT to the Judicial Confenence of the Commituee on Punishatent for Crime (r94I) 3r, 32, 33. 
tween $x_{7}$ and 20 , inclusive, are arrested for major crimes in greater numbers than persons of any other 4-year group. They are arrested for serious crimes twice as often as adults from 35 to 39 , inclusive, three times as often as those from 45 to 49 , inclusive, and five times as often as those from 50 to 59 , inclusive. Nineteen-year-olds offend more frequently than persons of any other age. Eighteen-year-olds come next. Moreover, the proportion of youths less than 2I in the whole number of persons arrested is increasing at an alarming rate. ${ }^{2}$ [ ${ }^{2}$ The Criminality of Youth, Thorsten Sellin, pp. 37-55.] This tremendous upsurge of criminality during the youth period is a startling social phenomenon. ${ }^{3}\left[{ }^{3}\right.$ See Criminal Youth and the Borstal System, Healy and Alper, Pp. 5-10; Youth in the Toils, Harrison and Grant, pp. 44-48.]

In $194 \mathrm{I}$, there were 33,429 persons convicted of Federal offenses. Of these, 7,393 , or 22.I per cent, were under 24 years of age. Of the youthful offenders, 1,153 were under 18 years of age, 2,804 were in the age group 18 to 20 , inclusive, $I, I$ ro were $21, I, I 47$ were 22, and 1,179 were 23 years of age.

Thirty-seven and one-half per cent of the violators of the Motor Vehicle Theft Act were youthful offenders. Violations of that act constituted 57.9 per cent of all Federal offenders in rg4r. . . .

It would seem from the foregoing that we must wisely concentrate our efforts to prevent crime upon the offenders in the age group between 16 and 23 , if we are to make progress in the solution of our crime problem.

Sociologists and psychiatrists tell us that special causations, which occur in the period between adolescence and manhood, produce these antisocial conduct trends. ... .

Again, reliable statistics demonstrate with reasonable certainty that existing methods of treatment of criminally-inclined youths are not solving the problem. A large percentage of those released from our reformatories and penal institutions return to antisocial conduct and ultimately become hardened and habitual criminals. ...

The underlying theory of the provisions for treatment of youth offenders is to substitute for retributive punishment, methods of training and treatment designed to correct and prevent criminal tendencies. The plan of the act departs from the merely punitive idea of dealing with youthful offenders and looks primarily to the objective idea of rehabilitation. It will be observed that youth offenders are to be segregated from other offenders and that classes of youth offenders are to be segregated from other classes of such offenders, and that each youth offender is to be allocated to a treatment agency or institution best calculated to effect his rehabilitation.

The practicality and desirability of such a system of corrective treatment and training has been demonstrated by the Borstal System in England which started with an experimentation in a wing of Bedford Prison and now embraces II institutions, five of which are walled and four of which are completely open. ${ }^{\top}$

With respect to adult offenders, the definite sentence is to be fixed in the light of information obtained by penal experts from a study of the offender over a substantial period after his conviction, supplemented by the pre-sentence report of probation officers and other information. It should result in more scientific sentencing and

\footnotetext{
${ }^{7}$ For a more detailed statement respecting the Borstal system, see Report of Subcommittee on Treatment of Youthful Offenders, RePORT, supra note 6, at 36-39; Tolman, The Borstal System, id. App. II, pp. $53-70$.
} 
should largely eliminate shocking disparities that from time to time occur in the sentencing of adult offenders under like facts and circumstances.

The Committee has also recommended a separate act providing that any person arrested for an offense against the United States, subject to the approval of the court having jurisdiction over the person and the offense, may in writing waive indictment by grand jury and consent to be charged by information, and may enter a plea of guilty to the information, or consent to a trial upon the information before the court without a jury. The purpose of this act is to permit persons desirous of pleading guilty or waiving trial by jury, to do so without being subjected to the contaminating influence of confinement in jails awaiting return of indictments by grand juries and trials by petit juries.

The proposed act, in my opinion, will provide an integrated and coordinated correctional system. It will provide for a more adequate and effective supervision of parolees and youth offenders under conditional discharge. It will make possible better sentencing in cases of adult offenders and effect the rehabilitation of a large proportion of youth offenders. It is the result of a most thorough and comprehensive study of the whole subject by the Committee which is reflected in its report, copies of which may be obtained from the Director of the Administrative Office of the United States Courts, Supreme Court Building, Washington, D. C.

If the proposed act is enacted into law, the result, in my judgment, will be a great forward step in criminal justice under the federal system. 